Jurnal Pujangga Volume 6, Nomor 2, Desember 2020

ISSN P 2443-1478

ISSN E 2443-148

\title{
BAHASA INDONESIA RAGAM TULIS MAKALAH MAHASISWA FAKULTAS HUKUM UNIVERSITAS NASIONAL JAKARTA
}

\author{
Kasno Atmo Sukarto \\ Universitas Nasional Jakarta \\ 0817767736 \\ kasnoas@yahoo.com \\ Musril Zahari \\ Sekolah Tinggi Ilmu Ekonomi Indonesia \\ 08128216325 \\ bagindo_mz@yahoo.com
}

Received Sept 14, 2020, Revised Sept 30, 2020 , Approved Oct 15, 2020

\begin{abstract}
ABSTRAK
Ragam Bahasa Indonesia ragam tulis merupakan ragam bahasa tulis yang dipakai dalam situasi resmi dalam makalah atau karya tulis ilmiah. Makalah yang dimaksud adalah karya tulis ilmiah yang dibuat oleh mahasiswa Fskultas Hukum Universsitas Nasional, Jakarta pada akhir semester. Oleh karena itu, mahasiswa di dalam menulis makalah, hendaknya akan lebih baik dan benar jika menerapkan kaidah ejaan, pailihah kata yang tepat sesuai dengan konteks, dan menerapkan kaidah penulisan kalimat efektif. Tujuan penulisan ini adalah memaparkan ikwal kekeliruan penerapan ejaan, pemilihan kata, dan pengalimatan. Di dalam penelitian ini, yang diterapkan metode deskriptfkualitatif, yakni mendeskripsikan data-data terpilih sesuai dengan ancangan penelitian. Kerangka teori yang diterapkan dalam menganalisais data adalah Pedoman Umum Ejaan Bahasa Indonesia Indoesia (PUEBI) dan Kalimat Efektif: Diksi, Struktur, dan Logika. Hasil analisis terlihat bahwa dalam ragam tulis bahasa Indonesia makalah mahasiswa Fakultas Hukum Universiats Nasional, masih terdapat adanya kekeliruan dalam penerapan kaidah ejaan bahasa Indonesia, diksi, dan pengalimatan yang belum efektif.
\end{abstract}

Kata kunci: ragam tulis, ejaan, diksi, kalimat efektif

\begin{abstract}
Writing system of Indonesian language is applied in formal situation both in papers and scientific studies. Papers in this case refers to the final year students' writing in faculty of Law, National University, Jakarta. In writing papers, they are expected to write correctly following the system. Such as applying language spelling, using a proper words, and applying effective sentences. The aims of this study somehow, to describe the misappropriation of spelling, word selection, and wording. This study comprises a qualitative-descriptive method, that is describing the selected data in accordance with the research approach. The theoretical framework applied in analyzing data is Pedoman Umum Ejaan Bahasa Indonesia (PUEBI) and Effective Sentences: Diction, Structure, and Logic. The results of the analysis shows that there are still errors in languge spelling, diction, and ineffective sentences in of the final year students in faculty of Law, National University, Jakarta
\end{abstract}

Keywords: writing system, spelling, diction, effective language 
Jurnal Pujangga Volume 6, Nomor 2, Desember 2020

ISSN P 2443-1478

ISSN E 2443-148

\section{PENDAHULUAN}

\section{Latar Belakang}

Bahasa Indonesia sebagai alat komunikasi mencakup dual hal yaitu ragam lisan dan ragam tulisan. sebagai ragam lisan ditunjang adanya situasi pemakaian (Sunaryo, 2000: 24). Bahasa Indonesia ragam lisan dipakai oleh penutur bahasa dalam konteks resmi dan tidak resmi. Dalam konteks resmi dan tidak resmi ragam lisan menghendaki adanya teman tutur, tidak selalau menerapkan adannya fungsi gramatikal, dan sangat terikat adanya situasi, kondisi, tempat dan intonasi. (Sukarto: 2018: Dalam konteks resmi ragam lisan dipakai dalam acara rapat dinas, lembaga pendidikan, baik di lembaga pemerintah maupun lembaga swasta. Sehubungan dengan itu, penutur mempertimbangkan teman tutur, dan strata sosial, dan fungional. teman tutur mengharuskan adanya pertimbangan kosakata yang dipakai agar tidak menyulitkan teman tutur dalam memaknai kosakata yang dipakai oleh penutur. Adapun strata sosial yang dimaksud adalah yang sebagian norma dan kaidahnya atas dasar kesepakatan bersama dalam lingkungan sosial. Terkait dengan strata fungsional, ragam bahasa yang dipakai adalah dikaitkan dengan profesi, lembaga lingkungan kerja atau kegiatan tertentu lainnya. misalnya dalam lingkungan keilmuan; laras bahsa hukum atau laras bahasa kedokteran (Sukarto, 2018: 24-27)

Berkaitan dengan konteks bahasa ragam tulis, penulis dalam membuat karya ilmiah (makalah) tidak ditunjang adanya situasi pemakaian. Selain itu, ragam tulisan juga tidak mengaharuskan adanya teman tutur, tetapi mengharapkan adanya kelengkapan gramatikal, bentuk kata, pola kalimat dan tanda baca. Kelengkapan gramatikal yang dimaksud adalah dalam sebuah kalimat hendaknya lengkap struktur kalimat dan pola kalimat. Selain itu, adanya kaidah ejaan, dan diksi perlu disikapi dengan baik, agar tulisan yang dibuat dapat dipahmi oleh pembaca tanpa harus bertanya-tanya tentang maksud dan tujuan penulis.

Untuk mengetahui bahasa Indonesia ragam tulis makalah yang telah dibuat oleh mahasiwa Fakultas Hukum Univetrsiyas Nasisonal, Jakarta dapat dilihat seperti kasus di bawah ini.

1. Dr. Sudino SH, dalam bukunya Mengenal Hukum (1986: 117) sumber hukum digunakan dalam bebera arti. ( SIPJ/2019/5)

Kalimat nomor (1) terdapat kekeliruan dalam penerapan ejaan khususnya dalam penulisan gelar, dan penulisan judul buku yang telah dikutip. Untuk itu, sesuai dengan kaidah ejaan bahwa Huruf kaital dipakai sebagai huruf pertama unsur singkatan nama gelar, pangkat atau sapaan (PUEBI, 2016: 12). Sesuai dengan kaidah ejaan itu, bahwa penulisan kalimat nomor (1) seharusnya seperti 
Jurnal Pujangga Volume 6, Nomor 2, Desember 2020

ISSN P 2443-1478

ISSN E 2443-148

berikut. Selain itu, bisa ditulis sesuai dengan aturan mengutip adalah tidak harus menulis nama, gelar, dan judul buku, cukup menulis nama belakang dan tanpa harus menulis judul bukunya.

(1b) Sudino (1986: 117) sumber hukum digunakan dalam beberapa arti. (SIPJ/2019/5)

Berkaitan dalam diksi dalam kalimat dapat dilihat seperti kasus berikut ini.

2. Subyek penelitian merupakan sumber informasi untuk mencari data dan masukan-masukan dalam mengungkapkan masalah penelitian atau dikenal dengan informasi yaitu orang yang dimanfaatkan untuk memberi informasi (DN/2019/4).

Kalimat (2) pilihan diksi subyek adalah bukan kata baku. Untuk itu, yang baku adalah subjek. Untuk kata ulang masukan-masukan tidak harus ditulis ulang, cukup ditulis masukan. dengan demikian, kalimat (2) seharusnya seperti berikut.

2a. Subjek penelitian merupakan sumber informasi untuk mencari data dan masukan dalam mengungkapkan masalah penelitian atau dikenal dengan informasi yaitu orang yang dimanfaatkan untuk memberi informasi (DN/2019/4).

3. Saat ini banyak sekali terjadi tindak pidana penganiayaan yang dilakukan oleh masyarakat Indonesia yang dipengaruhhi oleh berbagai faktor, diantaranya seperti faktor ekonomi, lingkungan dan lain sebagainya. (MRM/2019/4).

Kasus kalimat (3) adalah penggunaan kata sekali dan penulisan kata diantaranya. Kata banyak sekali cukup ditulis banyak. Kata diantaranya seharusnya ditulis di antaranya. Jadi, kaliamt nomor (3) seharusnya seperti berikut.

3a. Saat ini banyak terjadi tindak pidana penganiayaan yang dilakukan oleh masyarakat Indonesia yang diengaruhi oleh berbagai faktor, di antaranya seperti faktor ekonomi, lingkungan, dan lain sebagainya. (MRM/2019/4).

Kasus seperti tersebut di atas, kita jumpai dalam ragam tulis makalah mahasiswa Fakultas Hukum, Universitas Nasional, Jakarta. Namun, hal itu terjadi karena mahasiswa belum cermat dalam menyikapi kaidah ejaan, diksi, dan kalimat efektif. Padahal, dalam ragam Bahasa hukum bahwa kaidah ejaan, diksi, termasuk kalimat efektif mepunyai makna yang berarti dalam bidang hukum. Apalagi berkaitan dengan berita acara hukum, kasus hukum, baik hukum pidana maupun 
ISSN P 2443-1478

ISSN E 2443-148

hukum perdata. Selain itu, bahwa kata, frasa, klausa, dan kalimat yang berkaiatan dengan bidang hukum mempunyai arti dan makna yang perlu dipertimbangkan kegunaannya.

Kecenderungan mahasiswa yang kurang memperhatikan peran pentingnya kaidah ejaan, diksi dan kalimat efektif ini menjadi perhatian penulis untuk diteliti lebih lanjut. Hal itu, dilakukan mengingat, mahasiswa Fakultas Hukum, Universitas Nasional sebagai calon ahli hukum, pengamat hukum rasanya tidak keliru jikak diarahkan dan dibina bagiamana penting- nya laras bahasa hukum di Indonesia ini agar lebih dimengerti dan dipahami. Dengan adanya pembinaan dan pengembangan yang dilakukan oleh pengampu mata kuliah Bahasa Indonesia diharapkan penulisan mahasiswa berikutnya akan lebih baik lagi.

\section{Rumusan Masalah}

Berdasarkan paparan pada latar belakang masalah, penulian difokuskan pada hal berikut.

1. Kesalahan penerapan kaidah ejaan seperti apa yang terdapat dalam makalah mahasiswa Fakultas Hukum, Universitas Nasional.

2. Kesalahan pilihan kata seperti apa yang terdapat dalam makalah mahasiswa Fakultas Hukum, Universitas Nasional.

3. Pengalimatan seperti apa yang terdapat dalam makalah mahasiswa Fakultas Hukum, Universitas Nasional.

\section{Tujuan Penulisan}

Penulian ini bertujuan untuk

1. mendeskripsikan dan menganalisis kesalahan penerapan kaidah ejaan makalah mahaiswa Fakultas Hukum, Universitas Nasional;

2. mendeskripsikan dan menganalisis pilihan kata makalah mahasiswa Fakultas Hukum, Universitas Nasioanal;

3. mendeskripsikan dan mennganalisis pengalimatan makalah mahasiswa Fakultas Hukum, Universitas Nasioanal. 
Jurnal Pujangga Volume 6, Nomor 2, Desember 2020

ISSN P 2443-1478

ISSN E 2443-148

\section{Tinjauan Pustaka}

\section{Ikhwal Bahasa}

Bahasa di dalam kehidupan bermasyarakat merupakan alat komuniksi yang digunakan dalam bentuk lisan dan tulisan. Indiyastini (2015: 3). Selain itu, Bahasa yang dipakai--dapat mendukung maksud atau pikiran dan perasaan pembicara secara jelas. (Putrayasa, 2014: 1) Sebagai ragam lisan, Bahasa Indonesia dipakai oleh masyakat baik dalam situasi resmi maupun tidak resmi. Sebagi bahasa resmi dipakai dalam rapa dinas, seminar, dan acara resmi baik oleh lembaga pemerintah maupun swasta. Tidak resmi, berarti bahasa lisan dipakai komunikasi seharihari oleh anggota masyarat atau kelompok masyarakat tertentu. Dalam betuk tulisan, bahasa Indonesia dipakai di dalam karya tulis ilmiah atau makalah. Hal itu, misalnya tampak pada makalah atau karya tulis ilmiah yang dibuat oleh mahasiswa Fakultas Hukum, Universitas Nasional, Jakarta. Secara umum, mahasiswa sudah mendapat mata kuliah Bahasa Indonesia, tetapi pada kenyataannhya setelah mengerjakan tugas akhir masih ada saja terjadi kekurangcermatan dalam menyikapi kaidah bahasa Indonesia. Misalnya dalam mrnerapkan kaidah ejaan, diksi dan kalimat efektif.

\section{Bahasa Indonesia Ragam Tulis}

Berbicara tentang bahasa Indonesia ragam tulis adalah bagaimana khalayak pemakai bahasa Indonesia menuangkan gagasannnya ke dalam bentuk tulisan yang benar sesuai dengan kaidah bahasa Indonesia (Sukarto, 2018: 24). Ragam Bahasa Indonesia tulis di sini adalah ragam tulis ilmiah atau makalah yang telah dibuat oleh mahasiswa Fakuktas Hukum Universitas Nasional, Jakarta. Karya ilmiah yang dibuat oleh mahasiwa itu merupakan tugas akhir semester. Sementara terkait dengan topik dan judul yang telah diberikan kepada mahasiswa adalah yang terkait dengan konsentrasi masing- masing mahasiswa.

Ragam bahasa tulis yang telah dibuat oleh mahasiswa itu hendaknya sesuai dengan kaidah ragam Bahasa tulis seperti yang telah diancangkan oleh Yanti; Zabadi; Rahman (2016: 31) yang menyatakan bahwa bahasa ragam tulis adalah tidak mengharuskan adanya teman bicara di hadapan pembicara; harus lengkap struktur gramatikalnya karena tidak menghendaki pendengar berada di hadapan pembicara; dan ragam tulis tidak terikat pada kondisi, situasi, ruanag, dan 
Jurnal Pujangga Volume 6, Nomor 2, Desember 2020

ISSN P 2443-1478

ISSN E 2443-148

waktu. Sehubungan dengan pandangan Yanti; Zabadi, dan Rahman itu, terbukti bahwa dalam ragam bahasa tulisan yang pertama dalam ragam tulis harus jelas bagaimana cara menuangkan gagasan penulis agar dapat dipahami benar oleh pembaca, misalnya penerapan kaidah ejaan yang tepat dan benar berkaitan dengan penulisan huruf, penulisan kata, pemakaian tanda baca, dan penulisn unsur serapan.

Sehubunga dengan hal tetsebutv di atas, pilihan kata (diksi) dalam tulisan ragm tulisan juga harus jelas, misalnya dengan memilih kata yang tepat sesuai dengan konteks kalimat. Selain itu, dalam ragam bahasa tulis hendaknya menyikapi pemakaian kata-kata baku dalam karya ilmiahnya. Hal itu sejalan dengan pandangan Sukarto (2020: 4) yang menyatakan bahwa bahasa Indonesia ragam tulis masih mendapat perhatian dan tanggapan mahasiswa secara positif -dan perlu adanya penyelarasan satuan rencana pembelajaran-agar dapat meningkatkan kemauan dan keterampilan mahasiswa dalam menggunakaan bahasa Indonesia ragam tulis yang benar.

Selain penerapan kaidah dan diksi yang tepat, unsur berikut yang tidak kalah pentingnya adalah unsur gramatikal. Unsur gramatikal merupakan salah satu unsur ragam bahasa tulis yang dihasilkan dengan menggunakan tulisan atau rangkaian huruf sebagai unsurnya. (Aditya "Ragam Bahasa Indonesia: Pengertian, Fungsi, Ciri dan Contonhya” (diakses 29 Oktober 2020).

Berkaitan dengan masalah gramatikal, dalam makalah mahasiswa tersebut masih terlihat adanya kecenderungan adanya kekeliruan dalam membuat kliamat efektif. Misalnya penerapan kaidah ejaan, pilihan kata, dan pengalimatan yang kurang efektif. Hal itu sejalan dengan pandangan Putrayasa (2014: 1) yang menyatakan bahwa kalimat efektif merupakan kalimat yang baik dan benar-memenuhi persayaratan gramatikal dan-harus disusun berdasrkan kaidahkaidah yang berlaku — dengan memperhatikan ejaan, diksi yang tepat dalam kalimat. Oleh karena itu, kalimat efektif tidak terlepas dari penerapan kaidah yang benar, pilihan kata yang tepat sesuai dengan konteks, dan pengalimatan yang benar. Dengan demikian, karya ilmiahnya dapat dipahami oleh pembaca atau pendengar (ketika dibaca). Selain itu, kalimat efektif hendaknya menerapkan struktur kalimat secara benar karena bisa saja terjadi kalimat tidak adanya subjek. Bahkan ada juga kalimat yang tidak berpredikat. dengan kata lain, kalimat tidak ada subjek dan predikat berrti bukan kalimat.

Paparan tersebut di atas telah diperkuat oleh Moeliono (2017: 7) yang menyatakan bahwa bahasa yang digunakan dalam ragam tulis harus disusun secara lebih cermat — fungsi gramatikal— 
Jurnal Pujangga Volume 6, Nomor 2, Desember 2020

ISSN P 2443-1478

ISSN E 2443-148

seperti subjek, predikat, dan objek-dan hubungan antara fungsi-fungsi itu harus jelas. Denga demikian, kalimat yang telah ditulis akan lebih jelas dan mudah dapahami oleh pembaca.

Hubungan dengan fungsi gramatikal, di dalam kalimat yang telah ditulis oleh oleh mahasiswa, berikutnya adalah masalah pengalimatan atau lebih lazim disebut kalimat efektif. Kecenderungan mahsiswa di dalam karya tulisnya, masih belum sepenuhnya menyikapi kaidah atau ciri kalimat efektif. Kalimat efektif merupakan kalimat yang dapat menyampaikan gagasan penulis, sehingga maksud penulis dapat dimengerti dan dipahami isinya tanpa harus bertanyatanya. Dengan kata lain, kalimat efektif telah memenuhi syarat penerapan kaidah ejaan tentang penulisan huruf, penulisan kata, dan penerapan tanda baca.

Dalam kriteria kalimat efektif, kalimat dalam ragam tulis atau makalah setidaknya mahasiswa menyikapi kaidah Bahasa yang berlaku, Sukarto (2018: 143-149) seperti 1) Kesepadanan, penekanan pada ide pokok kalimat yang dipakai. 2) Ketegasan, penekanan pada ide pokok kalimat dan meletakkan kata yang ditonjolkan. 3) Keparalelan, kesamaan bentuk yang digunakan dalam kalimat. 4) Kehematan, hemat menggunakan kata, frasa, atau bentuk lain yang dinggap tidak perlu. 5) Kecermtan, kalimat tidak menimbulkan tafsir ganda. 6) Kepaduan, informasi pernyataan dalam kalimat tidak terpecah-pecah. 7) Kelogisan, ide kalimat dapat diterima akal dan penulisannya telah menyikapi kaidah ejaan yang berlaku.

Atas dasar paparan di atas, bahwa dalam bahasa tulis makalah mahasiswa perlu ditindaklanjuti untuk diteliti lebih lanjut. Hal itu, mengingat kekeliruan dan kesalahan yang terjadi perlu dipaparkan dan dianalisis. Adapun hasilnya diharapkan dapat sebagai acuan dasar bagi mahasiswa agar tulisan berikutnya dapat lebih baik dan benar.

\section{METODE PENELITIAN}

Dalam penelitian ini, penulis menerapkan metode deskriptif-kualitiatif yakni mendeskripsikan data yang terpilih yang terdapat dalam sumber data. Oleh karena itu, dalam metode ini mengacu pada pandangan Sudaryanto (2001: 5) yang menyatakan bahwa terdapat tiga tahap dalam prosedur pengkajian yaitu penyediaan data, penganalisisan data, dan penyajian hasil analisis data. Adapun tahapan pengumpulan data seperti berikut.

Pada tahap penyediaan data, penulis mengumpulkan sumber data yang diprediksi terdapat data yang akurat, menandai data, mengklasifikasi data, dan menganalisis data. Pada tahap penganalisisan yang dilakukan adalah penulis mendeskripsikan dan menganalisis data yang 
terpilih. Pada tahap penyajian hasil analisis, penulis mengklasifikasi kekeliruan penerapan kaidah ejaan, pilihan kata (diski), dan kalimat efektif. Setelah itu, penulis menganalisis data yang keliru dalam menerapkan kaidah ejaan, pilihan kata, dan kalimat efektif.

Sumber data penelitian ini adalah makalah mahasiswa Fakultas Hukum, Universitas Nasional, Jakarta sejumlah 50 makalah tugas mata kuliah Bahasa Indonesia akhir semester genap tahun 2019/2020. Lebih lanjut, penulis memilah-milah dan memilih sumber data, ternyata terdapat 34 makalah yang laik untuk diteliti. Adapun data yang terpilih sesuai dengan ancangan penelitian ini adalah kesalahan penerapan kaidah ejaan, pilihan kata (diksi), dan kalimat efektif.

\section{HASIL DAN PEMBAHASAN}

Dalam hasil dan pembahasan ini akan dideskripsikan dan dianlisis data yang berkaitan dengan kesalahan penerapan ejaan, pilihan kata (diski), dan kalimat efektif. Adapun data yang diperoleh dan telah diklasikfikasikan berdasarkan ancanganpenelitian adalah seperti berikut.

\section{Penerapan Kaidah Ejaan}

\section{Penggunaan Tanda Titik dua (:)}

Kasus pemakaian Titik Dua (;) dapat dilihar pada contoh di bawah ini.

1) Di dalam sebuah sistem hukum terdapat unsur-unsur yang membangun sistem tersebut yaitu:

1. Peraturan yang mengatur tingkah laku manusia dalam kehidupan bermasyarakat

2. Peraturan yang ditetapkan oleh instansi resmi negara

3. Peraturan yang bersifat memaksa

4. Peraturan yang memiliki sanksi tegas. (SIPJ/2019/10)

Sesuai dengan Pedoman Umum Ejaan Bahasa Indonesia yang berkaitan dengan tanda titik dua (:) adalah seperti berikut. Tanda titik dua dipakai pada akhir suatu pernyataan lengkap yang diikuti pemerincian atau penjelasan.

Misalnya:

Mereka memerlukan perabot rumah tangga: kursi, 
ISSN P 2443-1478

ISSN E 2443-148

meja, dan lemari. (PUEB, 2016: 45-46).

Pada kasus kalimat (1) terdapat kekeliruan penerapan penulisan huruf setelah tanda baca titik dua (:). Setelah tanda titik dua (:) seharusnya penulisan pamerincian nomor $1-4$ seharusnya ditulis huruf awal huruf kecil dan pada akhir rincian diakiri dengan membubuhkan tanda koma (,), setelah tanda koma (,) sebelum penulisan unsur akhir diberi konjungsi dan atau titik koma (;). Dengan demikian, kalimat 1) seharyusnya seperti berikut.

1a) Di dalam sebuah sistem hukum terdapat unsur-unsur yang membangun sistem tersebut yaitu:

1. peraturan yang mengatur tingkah laku manusia dalam kehidupan bermasyarakat,

2. peraturan yang ditetapkan oleh instansi resmi negara,

3. peraturan yang bersifat memaksa, dan

4. peraturan yang memiliki sanksi tegas. (SIPJ/2019/10)

Tanda titik koma dipakai untuk memisahkan bagian-bagian pemerincian dalam kalimat yang sudah menggunakan tanda koma. (PUEBI: 2016: 44)

Dalam kalimat 1a, bisa juga diberi tanda titik koma (;), tetapi sebelum unsur akhir setelah tanda titik koma (;) tanpa konjungsi dan, tetapi ada juga yang cenderung menggunakan konjungsi dan setelah titik koma akhir (;). Sehubungan dengan kitu, kalimat 1a) dapat ditulis seperti berikut ini.

1b) Di dalam sebuah sistem hukum terdapat unsur-unsur yang membangun sistem tersebut yaitu:

1. peraturan yang mengatur tingkah laku manusia dalam kehidupan bermasyarakat;

2. peraturan yang ditetapkan oleh instansi resmi negara;

3. peraturan yang bersifat memaksa;

4. peraturan yang memiliki sanksi tegas. (SIPJ/2019/10)

Jika kalimat pemerincian tetap menggunakan huruf awal huruf kapital, kaliamt 1) dapat diperbaiki dengan cara mengganti kata yaitu dengan frasa sebagai berikut, yang diakhiri dengan tanda titik (.). Dengan demikian, kalimat 1) seperti berikut.

1c) Di dalam sebuah sistem hukum terdapat unsur-unsur yang membangun sistem sebagai berikut. 
Jurnal Pujangga Volume 6, Nomor 2, Desember 2020

ISSN P 2443-1478

ISSN E 2443-148

1. Peraturan yang mengatur tingkah laku manusia dalam kehidupan bermasyarakat,

2. Peraturan yang ditetapkan oleh instansi resmi negara,

3. Peraturan yang bersifat memaksa, dan

4. Peraturan yang memiliki sanksi tegas. (SIPJ/2019/10)

atau

1d) Di dalam sebuah sistem hukum terdapat unsur-unsur yang membangun sistem sebagai berikut.

1. Peraturan yang mengatur tingkah laku manusia dalam kehidupan bermasyarakat;

2. Peraturan yang ditetapkan oleh instansi resmi negara;

3. Peraturan yang bersifat memaksa;

4. Peraturan yang memiliki sanksi tegas. (SIPJ/2019/10)

Pada kasus yang sama dapat dilihat pada contoh kalimat nomor 2) berikut ini.

2) Berangkat dari latar belakang dan rumusan masalah yang telah dipaparkan diatas, karya tulis ini dibuat dengan tujuan untuk:

1. Mengetahui aturan baku dalam penggunaan SKA Form AK.

2. Mempermudah importir dalam menggunakan fasilitas kepabeanan SKS Form AK.

$(\mathrm{AAV} / 2019 / 6)$

Kalimat nomor 2) jika cenderung menemptkan tanda titik dua (;) hendaknya seperti berikut.

2) Berangkat dari latar belakang dan rumusan masalah yang telah dipaparkan diatas, karya tulis ini dibuat dengan tujuan untuk:

1. mengetahui aturan baku dalam penggunaan SKA Form AK,

2. mempermudah importir dalam menggunakan fasilitas kepabeanan SKS Form AK. $(\mathrm{AAV} / 2019 / 6)$

Penggunaan Tanda Titik satu (.) dalam singkatan 
ISSN P 2443-1478

ISSN E 2443-148

Penggunaan tanda titik satu (.) dapat dijumpai seperti kasus berikut ini.

3) Puji syukur kehadirat Allah SWT, Tuhan Yang Maha Esa atas segala rahmat-Nya sehingga makalah ini dapat tersusun hingga selesai. (NRP/2019/1)

Penulisan singkatan SWT seharusnya Huruf $S$ ditulis huruf kapital dan huruf $W$ dan $T$ ditulis huruf kecil yang dikhiri dengan tada titik satu (.). dan melesapkan kata sehingga. Kalimat 3) seharusnya seperti berikut ini.

3a) Puji syukur kehadirat Allah Swt., Tuhan Yang Maha Esa atas segala rahmat-Nya, makalah ini dapat tersusun hingga selesai. (NRP/2019/1)

\section{Penulisan Nama Pengarang dalam Kutipan}

Dalam kasus kutipan dapat kita lihat pada conbtih berikut.

4) Kutipan: Dr. Sudino SH, dalam bukunya Mengenal Hukum (1986: 117) sumber hukum itu digunakan dalam bebera arti. ( SIPJ/2019/5)

5) Mariam Budiarto, menyatakan "Hak - Hak asasi manusia sebagai hak yang dimiliki manusia yang telah diperoleh dan dibawa bersamaan dengan kelahirannya/ kehadirannya di masyarakat." (GBP/2019/5)

6) Koentjoro Poerbopranoto (1976), menyatakan "hak asasi manusia adalah hak yang bersifat asasi, artinya hak-hak yang dimiliki manusia merupakan kodratnya yang tidak bisa dipisahkan dari hakikatnya sebagai sifatnya yang suci." (GBP/2019/5)

7) Menurut Lilian Tedjosaputro Penegakan hukum yang bersifat preventif adalah usaha pencegahan kejahatan, upaya untuk menjaga agar orang yang bersangkutan serta masyarakat pada umumnya tidak melakukan kejahatan (SHS/2019/5)

8) Menurut kamus besar Bahasa Indonesia versi online (9kbbi daring), syariat hukum agama yang menetapkan peraturan hidup manusia, hubungan manusia dengan allah swt., hubungan manusia dengan manusia dan alam sekitar berdasarkan alquran dan hadist. (CMG/2019/2)

Pada kalimat 4) terdapat kekeliruan dalam penulisan nama gelar dan penulisan judul buku. Penukian judul buku hendaknya ditulis huruf miring. kalimat 5) kekeliruan pada penulisan nama dalam kutipan. penulisan nama Mariam Budiarto, seharusnya tidak ditulis lengkap, cukup menulis nama belakang yaitu Budiarto. Penulisan Judul HAM juga ditulis huruf awal dengan huruf 
Jurnal Pujangga Volume 6, Nomor 2, Desember 2020

ISSN P 2443-1478

ISSN E 2443-148

kapital. Kalimat 6) Koentjoro Poerbopranoto, cukup ditulis Poerbopranoto. Kalimat 7) juga cukup ditulis nama belakang, yaitu Tedjosaputro. Kalimat 8) Judul buku hendaknya ditulis miring per kata atau digarisbawahi per kata. Selain itu, kata alquran dan hadis ditulis Alquran dan hadis Dengan demikian, kalimat 4), 5), 6), 7), dan 8) seperti berikut.

4a) Sudino, dalam bukunya Mengenal Hukum (1986: 117) sumber hukum itu digunakan dalam bebera arti. ( SIPJ/2019/5)

5a) Budiarto, menyatakan "Hak-Hak Asasi Manusia sebagai hak yang dimiliki manusia yang telah diperoleh dan dibawa bersamaan dengan kelahirannya/ kehadirannya di masyarakat." $(\mathrm{GBP} / 2019 / 5)$

6a) Poerbopranoto (1976), menyatakan "hak asasi manusia adalah hak yang bersifat asasi, artinya hak-hak yang dimiliki manusia merupakan kodratnya yang tidak bisa dipisahkan dari hakikatnya sebagai sifatnya yang suci." (GBP/2019/5)

7a) Menurut Tedjosaputro penegakan hukum yang bersifat preventif adalah usaha pencegahan kejahatan, upaya untuk menjaga agar orang yang bersangkutan serta masyarakat pada umumnya tidak melakukan kejahatan (SHS/2019/5)

8a) Menurut Kamus Besar Bahasa Indonesia versi online (9kbbi daring), syariat hukum agama yang menetapkan peraturan hidup manusia, hubungan manusia dengan Allah Swt., hubungan manusia dengan manusia dan alam sekitar berdasarkan Alquran dan hadis. (CMG/2019/2)

\section{Penulisan Kosakata Asing}

9) Perkembangan Sistem Hukum Indonesia yang cenderung lebih memilih civil law dan coomion law system dan politik hukum Indonesia yang mengarah pada kodefikasi. (GBP/2019/3)

Penulisan unsur asing pada kalimat 7) jika memang belum ada padanannya dalam Bahasa Indonesia cukup diberi garis pada setiap kata. Untuk itu, unsur kosakata asing/bahasa Inggris tersebut seharusnya ditulis seperti berikut ini.

9a) Perkembangan Sistem Hukum Indonesia yang cenderung lebih memilih civil law dan coomion law system dan politik hukum Indonesia yang mengarah pada kodefikasi. (GBP/2019/3) 
Jurnal Pujangga Volume 6, Nomor 2, Desember 2020

ISSN P 2443-1478

ISSN E 2443-148

\section{Pilihan Kata (Diski)}

Berkaitan dengan penulisan kata/penulisaan kata, terdapat kasus penulisan gabungan kata yang seharusnya dihindari. Hal itu dapat kita lihat pada kalimat di bawah ini.

10) Pertangung jawaban pidana adalah pertanggung jawaban orang terhadap tindak pidana yang dilakukannya. (KM/2019/7).

Gabungan kata yang mendapat awalan dan akhiran sekaligus ditulis serangkai.

Misalnya:

dilipatgandakan

menggarsibawahi

Sehubungan dengan itu, kalimat 10) seharusnya seperti di bawah ini.

10a) Pertangungjawaban pidana adalah pertanggungjawaban orang terhadap tindak pidana yang dilakukannya. (KM/2019/7).

\section{Penulisan Kata Baku dan Tidak Baku}

Berkaitan dengan penulisan kata baku dan tidak baku dapat kita jumpai pada kasus di bawah ini.

11) Subyek penelitian merupakan sumber informasi untuk mencari data dan masukan-masukan dalam mengungkapkan masalah penelitian atau dikenal dengan informasi yaitu orang yang dimanfaatkan untuk memberi informasi (DN/2019/4).

12) Adapun subyek penelitian yang dimaksud di sini adalah manajer perusahaan, bagian HRD/sumber daya manusia, dsan karyawan/SPV (DN/2019/4)

13) Obyek penelitian ini adalah sesuatu yang hendak diteliti dalam sebuah penelitian skripsi $(\mathrm{DN} / 22019 / 4)$

14) Obyek dalam penelitian ini adalah pengembangan SDM melaui motivasi kerja di perusahaan tersebut. (DN/2019/4) 
Jurnal Pujangga Volume 6, Nomor 2, Desember 2020

ISSN P 2443-1478

ISSN E 2443-148

Pada kalimat nomor 11), 12), 13), dan 14) terdapat kasus penulisan kata tidak baku subyek dan obyek yang seharusnya ditulis subjek dan objek. Oleh karena iu, kalimat 11)-14) dapat ditulis seperti di bawah ini.

11a) Subjek penelitian merupakan sumber informasi untuk mencari data dan masukan-masukan dalam mengungkapkan masalah penelitian atau dikenal dengan informasi yaitu orang yang dimanfaatkan untuk memberi informasi (DN/2019/4).

12a) Adapun subjek penelitian yang dimaksud di sini adalah manajer perusahaan, bagian HRD/sumber daya manusia, dsan karyawan/SPV (DN/2019/4)

13a) Objek penelitian ini adalah sesuatu yang hendak diteliti dalam sebuah penelitian skripsi $(\mathrm{DN} / 22019 / 4)$

14a) Objek dalam penelitian ini adalah pengembangan SDM melaui motivasi kerja di perusahaan tersebut. (DN/2019/4)

Kasus berikut adalah penulisan kata tidak baku seperti analisa, menganalisa, teoritis, dan resiko pada kalimat 15), 16), 17), dan 18).

15) Teknik analisa data dilakukan dengan menganalisa data non factual yakni data-data yang telah diperoleh baik secara manual dari buku-buku yang dan juga secara online. (RAA/2019?13)

16) Tujuan penelitian ini adalah untuk menganalisa dan memahami kronologi dari kasus tindak pidana korupsi, pencucian uang, dan penggelapan pajak oleh Gayus Tambunan. ( WES/2019/1)

17) Dalam penelitian teoritis ini penulis menggunakan pendekatan kualitatif. ( (RAA/2019/12)

18). Sangat penting diketahui, daalam kejadian pernikahan ini, resiko yang muncul tidak hanya fisik tetapi gangguan mental dan psikologis terjadi. (AN/2019/9)

Kalimat nomor 15) - 18) kata analisa, menganalisa, teoritis, dan resiko seharusnya ditulis analisis, menganalisis, teoretis, dan risiko. Dengan demikian, kalilmat 15-18) seperti beikut ini.

15a) Teknik analisis data dilakukan dengan menganalisa data nonfaktual yakni data-data yang telah diperoleh baik secara manual dari buku-buku yang dan juga secara online.

(RAA/2019?13) 
Jurnal Pujangga Volume 6, Nomor 2, Desember 2020

ISSN P 2443-1478

ISSN E 2443-148

16a) Tujuan penelitian ini adalah untuk menganalisis dan memahami kronologi dari kasus tindak pidana korupsi, pencucian uang, dan penggelapan pajak oleh Gayus Tambunan. (WES/2019/1)

17a) Dalam penelitian teoretis ini penulis menggunakan pendekatan kualitatif. ( (RAA/2019/12)

18a). Sangat penting diketahui, dalam kejadian pernikahan ini, risiko yang muncul tidak hanya fisik, tetapi gangguan mental dan psikologis terjadi. (AN/2019/9)

\section{Kalimt efektif}

\section{Konjungsi}

Kasus pemakiaan konjungsi tetap, namun dapat kita pada kalimat berikut ini.

19) Tetapi pada dasarnya tanggung jawab kebutuhan seseorang anak baik itu jasmani maupun psikis adalah mayoritas (FMMS/2019/2)

20) Namun di beberapa negara sering terjadi tindakan separatis karena sistem pemerintahan yang dianggap memberatkan rakyat ataupun merugikan rakyat. (AH/2019/4)

21) Indonesia menganut tiga sistem namun sampai saat ini negaranya sudah cukup baik dalam tujuan dan tatanan negaranya walaupun kurang maksimal dalam implementasinya sehinga kurang efisien di negara Indonesia sendiri. (RAPM/2019/2)

Pemakain konjungsi tetapi pada kalimat 19) kurang tepat karena konjungai tetapi merupakan konjungsi setara dalam kalimat majemuk setara. Dalam kalimat 20) penulisn konjungsi namun sudah benar, tetapi akan lebih tepat jika setelah namun dijeda dengan tanda koma (,) dan penulisan ataupun seharusnya juga dipisah. Kalimat 21) pemakaian konjungsi namun kurang tepat. Akan lebih tepat jika menempatkan konjungsi tetapi. Selain itu, juga adanya penempatan kata yang kurang tepat. Oleh karena, kalimat 19), 20) dan 21) seharusnya seperti di bawah ini.

19) Namun, pada dasarnya tanggung jawab kebutuhan seseorang anak baik itu jasmani maupun psikis adalah mayoritas. (FMMS/2019/2)

20) Namun, di beberapa negara sering terjadi tindakan separatis karena sistem pemerintahan yang dianggap memberatkan rakyat atau pun merugikan rakyat. (AH/2019/4) 
Jurnal Pujangga Volume 6, Nomor 2, Desember 2020

ISSN P 2443-1478

ISSN E 2443-148

21) Indonesia menganut tiga sistem, tetapi sampai saat ini negaranya sudah cukup baik dalam tujuan dan tatanan negaranya walaupun kurang maksimal dan kurang efisien implementasinya di negara Indonesia sendiri. (RAPM/2019/2)

\section{Konjungsi sebab dan karena}

Pemakaian konjungsi sebab dank karena dalam kalimat di bawah ini kurang tepat

22) Hal ini desebabkan karena korupsi di Indonesia terjadi secara sistemik dan luas sehingga bisa saja merugikan kondisi keuangan negara, tetapi juga telah melanggar hak-hak sosial ekonomi masyarakat secara luaas. (ANT/2019/5)

Kalimat 22) seharusnya bisa memilih salah satu konjungsi sebab atau karena. Oleh karena itu, kalimat 22) seharusnya seperti di bawah ini.

22a) Hal ini disebabkan korupsi di Indonesia terjadi secara sistemik dan luas sehingga bisa saja merugikan kondisi keuangan negara, tetapi juga telah melanggar hak-hak sosial ekonomi masyarakat secara luaas. (ANT/2019/5)

22) Hal ini dikarenakan korupsi di Indonesia terjadi secara sistemik dan luas sehingga bisa saja merugikan kondisi keuangan negara, tetapi juga telah melanggar hak-hak sosial ekonomi masyarakat secara luaas. (ANT/2019/5)

\section{Konjunsi sedangkan}

Konjungsi sedangkan dapat dilihat pada kalimat 23) di bawah ini.

23). Sedangkan perihal kewenangan, Mahkamah Konstitusi Republik Indobesia berwenang mengadili pada tingkat pertama dan terakhir yang putusannya bersifat final. (MAT/2019/4)

Klausa kedua menyatakan sesuatu yang bertentangan dengan apa yanag dinyatakan dalam klausa pertama. (Moeliono dkk. ,2017: 522). Dengan kata lain, konjungsi sedangkan tidak bisa sebagai klausa pertama. Sehubungn dengan pernyataan Moeliono, kalimat 23) seharusnya melesapkan konjunsi sedangkan agar jelas subjeknya seperti berikut ini.

23) Perihal kewenangan, Mahkamah Konstitusi Republik Indonesia berwenang mengadili pada tingkat pertama dan terakhir yang putusannya bersifat final. (MAT/2019/4) 
Jurnal Pujangga Volume 6, Nomor 2, Desember 2020

ISSN P 2443-1478

ISSN E 2443-148

\section{Konjungsi meskipun dan akan tetapi tetapi}

Kasus konjungsi meskipun, akan tetapi, dan teapi terlihat pada kalimat 24) dan 25) di bawah ini.

24) Sehingga meskipun aturan normatif tentang pelanggaran Asasi Manusia baru secara tegas diatur pada tahun 2000, akan tetapi pelanggarang Hak Asasi Manusia yang terjadi di masa lalu diharapkan dapat diselesaikan dengan seadil-adilnya. (MIG/2019/4)

25) Meskipun masalah pelanggaran Hak Asasi Manusia selalu saja mengundang suatu perdebatan, tetapi lepas dari kontroversi yang akan muncul dikemudian hari, proses terhadap peradilan Hukum Pidana Hak Asasi Manusia harus tetap berjalan dengan positif dan fair. (MIG/2019/16)

Kalimat 24) hendaknya melesapkan konjungsi sedangkan dan konjungsi akan tetapi. Dengan demikian kalimat 24) akan jelas induk kalimat/ kalimat utamanya dan anak kalimatnya. Oleh karena itu, kalimat 24 seperti berkut ini.

24a) Pelanggarang Hak Asasi Manusia yang terjadi di masa lalu diharapkan dapat diselesaikan dengan seadil-adilnya meskipun aturan normatif tentang pelanggaran Asasi Manusia baru secara tegas diatur pada tahun 2000. (MIG/2019/4)

Kalimat 25 pemakain konjungsi meskiun dan tetapi kurang tepat karena jika menggunakan dua konjungsi dalam satu tataran kalimat, kalimat tersebut tidak jelas mana induk klimat dan mana anak kalimat. Agar jelas induk dan anak kalimat 24) harus dilesapkan salah satu konjungsi yaitu konjungsi meskipun. Dengan demikian, induk kalimat adalah Masalah pelanggaran Hak Asasi Manusia selalu saja mengundang suatu perdebatan. Untuk itu, seharusnya kalimat 25 seperti berikutini.)

25a) Masalah pelanggaran Hak Asasi Manusia selalu saja mengundang suatu perdebatan, tetapi lepas dari kontroversi yang akan muncul dikemudian hari, proses terhadap peradilan Hukum Pidana Hak Asasi Manusia harus tetap berjalan dengan positif dan fair. (MIG/2019/16) 
ISSN P 2443-1478

ISSN E 2443-148

\section{PENUTUP}

\section{Simpulan}

Berdasarkan hasil dan pembahasan tentang kasus ejaan, pilihan kata, dan kalimat efektif dapat disimpulkan sebagai berikut. dalam ragam tulis makalah mahasiswa Fakultas Hukum, Universitas Nasional trdapat adanya penerapan kaidah yang keliru, misalnya pemakiaan tanda titik dua (;), tanda koma (,), titik koma (;) penulisan singkatan, penulisan kosakata asing, dan penulisan gelar dan nama pengarang dalam kutipan. Pilihan kata (diksi), yaitu penulian kata baku dan tidak baku. Kalimat efektif, misalnya penggunaan konjungsi yang kurang tepat, yaitu, konjungsi meskipun, tetapi, akan tetapi, sebab, karena, sedangkan, dan ketidak- jelasan subjek

\section{Saran}

Dalam penelitian sejenis memang masih banyak yang belum diteliti secara mendalam. Oleh karena itu, dalam hal bahasa ragam tulis ilmiah masih banyak yang bisa diteliti lagi, misalnya pengalimatan dalam hal penempatan konjungsi intra kalimat dan konjungsi antarkalimat. Penulisan gabungan kata dan unsur serapan juga masih perlu diteliti lebih lanjut. Selain itu, masalah interkresi dan interferensi juga perlu diteliti, mengingat gejala tersebut masih cenderung muncul dalam bahasa ragam tulis makalah mahasiswa. 


\section{DAFTAR PUSTAKA}

Aditya, Sukma. "Ragam Bahasa Indonesia: Pengertian, Fungsi, Ciri dan Contonhya" http:/saintif.com/ragam-bahasa-indonesia/ (diakses 29 Oktober 2020).

Indiyastini, Titik. 2015. "Tindak Tutur pada Wacana Perbintangan dalam Majalah Berbahasa Jawa". Prosiding: Diskusi Ilmiah (Lokakarya HaasilPenelitian) Kebahasaan dan Kesastraan. Yogyakarta: Balai Bahasa Daerah Istimewa

Yogyakarta; Universitas Islam Negeri Sunan Kalijaga Yogyakarta; Balai Pengkajian Komunikasi dan Informatika (BPPKI) Yogyakarta.

Moeliono, Anton M. dkk. 2017. Tata Bahasa Baku Bahasa Indonesia.Edisi Keempat.

Jakarta: Badan Pengembangan dan Pembinaan Bahasa. Kementerian Pendidikan dan Kebudayaan.

Tim Pengembang Pedoman Bahasa Inndonesia. 2016. Pedoman Umum Ejaan Bahasa Indonesia. Jakarta: Badan Pengembangan dan Pembinaan Bahasa, Kementeian

Pendidikan dan Kebudayaan.

Putrayasa, Ida Bagus. 2014. Kalimat Efektif. Diksi, Struktur, dan Logika. Edisi $\quad$ Revisi. Bandung: Refika Aditama.

Sudaryanto. 2001. Metode dan Teknik Analisis Bahasa. Pengantar Penelitian Wahana Kebudayaan secara Linguistik. Yogyakarta: Duta Wacana University Press.

Sukarto, Kasno Atmo. 2018. Bahasa Indonesia: dasar-Dasar Pengembangn Kepribadian.

Kota: Tangerang: Pustaka Mandiri.

Sukarto, Kasno Atmo. 2010. "Pemakain Bahasa Indonesia Karya Tulis Ilmiah oleh Mahasiswa Universitas Pembangunan Nasional'Veteran". Jakarta. Dalam Pujangga: Jurnal Bahasa dan Sastra. Volume 6. Nomor 1. Juni.

Sunaryo, Adi. 2000. Pilar-Pilar Bahasa Indonesia. Jakarta: Pusat Bahasa, Departemen Pendidikan Nasional.

Yanti, Prima Gusti; Fairul Zabadi; Fauzi Rahman. 2016. Bahasa Indonesia: Konsep Dasar dan Penerapan. Jakarta: Gramedia Widiasarana Indonesia. 